\title{
Prospects for the biological control of invasive Pinus species (Pinaceae) in South Africa
}

\author{
J.H. Hoffmann ${ }^{1 *}$, V.C. Moran ${ }^{1} \&$ B.W. van Wilgen ${ }^{2}$ \\ ${ }^{1}$ Zoology Department, University of Cape Town, Rondebosch, 7700 South Africa \\ ${ }^{2}$ Centre for Invasion Biology, CSIR Natural Resources and the Environment, P.O. Box 320, \\ Stellenbosch, 7599 South Africa
}

\begin{abstract}
Nine Pinus species (Pinaceae) have become invasive plants in South Africa after being deliberately introduced and cultivated in commercial forests, for timber. A proposal to use biological control to contain the problem raised concerns among foresters who immediately identified a number of difficulties that could arise for the forestry industry if biological control agents were to be introduced. As a compromise, plans were made to target, initially at least, two pine species, Pinus pinaster Aiton and Pinus halepensis Mill., that currently have no commercial value. A cone-feeding weevil from Portugal, Pissodes validirostris Gyllenhal (Coleoptera: Curculionidae), was identified as the most promising agent. Formerly regarded as a single species, extensive preparatory studies revealed that there are several different forms (perhaps a complex of sibling species) of $P$. validirostris each associated with different pine species in different regions of Europe. Screening tests in arboreta in France showed that the prospective agent was host-specific enough to be used with safety in South Africa. Despite this positive finding, the programme did not proceed much further because subsequent trials in quarantine in South Africa showed that damage caused by the adult weevils feeding on leader shoots of pines allowed ingress of pitch canker, Fusarium circinatum Nirenberg and O'Donnell (Hypocreales: Nectriaceae), an increasingly problematic pathogen in pine forests in South Africa. However, given the escalating negative consequences of pine tree invasions, especially in the Cape Floral Region, the question of whether or not this biological control programme should have been discontinued in 2009 remains open for debate and the opposing views on the subject are presented.
\end{abstract}

Key words: cone-feeding insects, Pissodes validirostris, Curculionidae, pine pitch canker, Fusarium circinatum, pathogen ingress, conservation.

\section{INTRODUCTION}

Of many Pinus species introduced since the early 1800s (Poynton 1979; Le Maitre 1998), nine are recognized as invasive plants in South Africa (Stirton 1978; Richardson \& Higgins 1998; Henderson 2001). Seven of these are categorized as 'transformer' species, i.e. plants that can 'dominate or replace any canopy or subcanopy layer of a natural or semi-natural ecosystem, thereby altering its structure, integrity and functioning' (Henderson 2001). Species of pines are widespread (Fig. 1) and, like many introduced, perennial plants in the country, they deplete valuable water resources (Van Lill et al. 1980; Van Wyk 1987; Scott \& Lesch 1996) and cause extensive environmental degradation (Richardson et al. 1996).

Suggestions that one or more of several species of cone-feeding insects (Roques 1976, 1983; Roques \& El Alaoui El Fels 2005) might be intro-

*To whom correspondence should be addressed.

E-mail: john.hoffmann@uct.ac.za duced into South Africa for biological control of invasive pine species were first mooted during the 1980s (S. Neser, pers comm.). At about the same time, New Zealand started considering biological control as a management option for wilding pines there, i.e. pines that had escaped into the wild and become invasive (Kay 1994; Brockerhoff \& Kay 1998; Brockerhoff et al. 2004). Nothing was done to pursue this approach in South Africa until funding was made available through Working for Water Programme (WfW) of the South African Department of Water Affairs in 1997 (Moran et al. 2000).

Four research organizations collaborated on the programme: in South Africa, the University of Cape Town, and the Agricultural Research CouncilPlant Protection Research Institute; and, in France, the Institut National de la Recherche Agronomique (INRA), and the University of Orleans. This grouping provided the facilities and skills needed to: (i) undertake surveys of the appropri- 


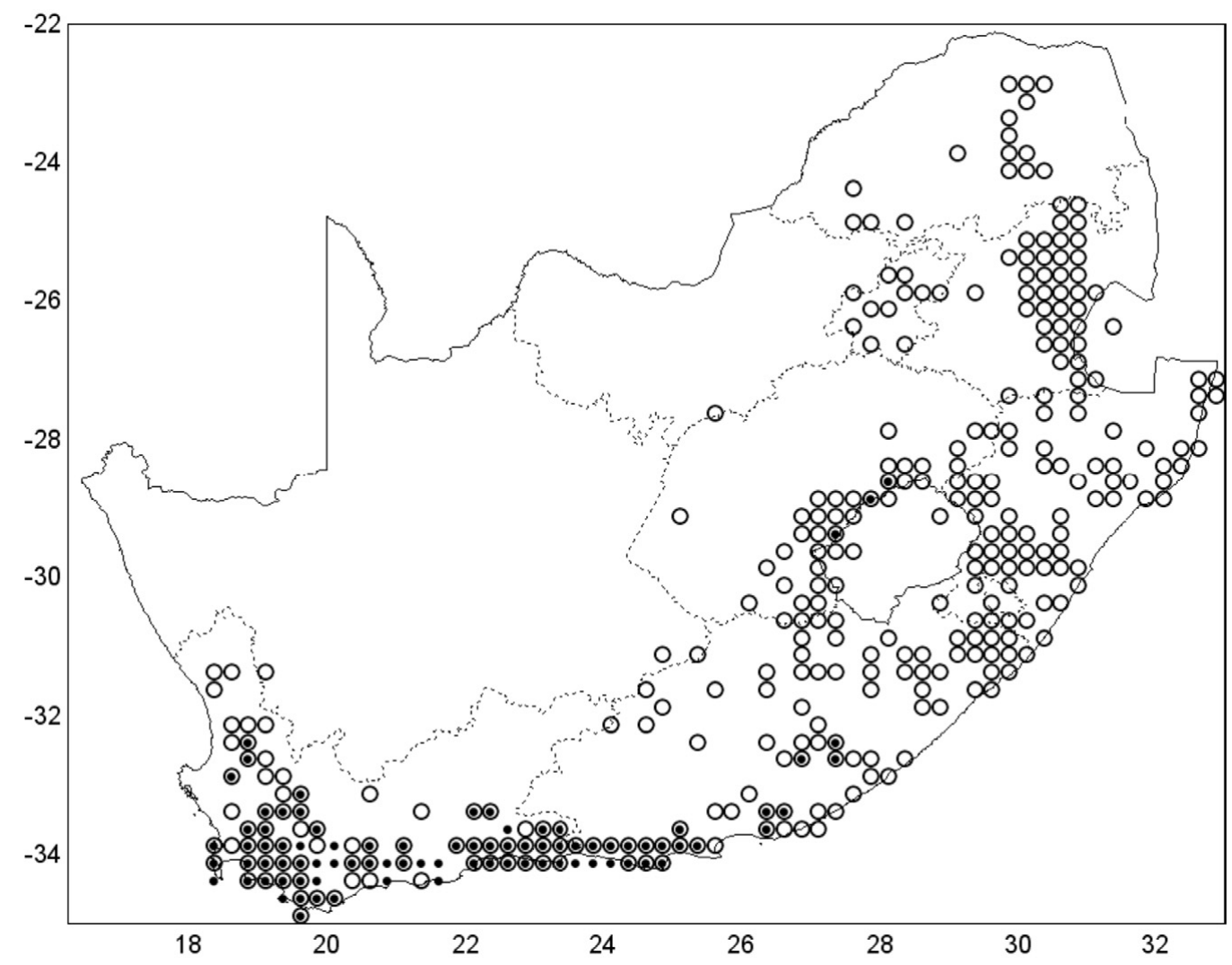

Fig. 1. Distribution of invasive Pinus species in South Africa. $\bullet$ Pinus pinaster; $O$, all other Pinus species. (Drawn by L. Henderson; data source: SAPIA database, ARC-Plant Protection Research Institute, Pretoria.)

ate species of pines throughout Europe; (ii) resolve the taxonomic status of potential agents and; (iii) conduct specificity and pathogenicity tests on potential agents in the field in Europe and in quarantine in South Africa.

This review summarizes developments with the project and provides an explanation of the conflicting interests and attitudes that eventually led to the discontinuation of the programme in 2009.

\section{RATIONALE FOR A BIOLOGICAL CONTROL PROGRAMME AGAINST PINES}

The benefits of pine-based forestry need to be weighed against the costs of pine invasions. Some of the introduced Pinus species are exploited commercially (Poynton 1979) and in the northeastern parts of the country cultivation of pines is generally profitable. However, in the Mediterranean-climate of the Western and Eastern Cape provinces, which include the uniquely species- rich fynbos biome of the Cape Floral Region (Cowling et al. 1997), plantation forestry using pine species is economically unsustainable (Venter 2001; DWAF 2004; Louw 2006).

Only $5.8 \%$ of South Africa's forest plantations are within the area occupied by the fynbos biome. Pines make up $87 \%$ of these plantations and, in 2009, generated R146 million in roundwood sales (Godsmark 2010). De Lange \& van Wilgen (2010) estimated that the loss of ecosystem services (mainly water) attributable to 'fire-adapted trees' (mainly pines) in the fynbos biome was R2 billion annually at current levels of infestation. At future potential levels of infestation, these impacts will increase as invasive pines spread and become denser. Towns, cities and rural areas between Cape Town and Port Elizabeth will experience water shortages that will constrain development and threaten human and animal health. The unique biodiversity of the Cape Floral Region will suffer severe degradation and loss of species. 
Recurring damage from the ever-escalating frequency of fires places additional burdens on an already beleaguered forestry industry. Accordingly, plans were made by the South African government to convert, over a 20 -year period, approximately 45000 ha of plantations, predominantly in the Cape Floral Region, to other forms of land use, mainly conservation (Louw 2004a,b, 2006; DWAF 2004, 2005), necessitating management strategies to deal with re-growth and feral infestations of pine trees. So, at a time when the pine-based forestry industry is shrinking, the gap between gains and losses becomes ever wider.

This situation in many ways mirrors that with some of the invasive Australian Acacia species (Mimosaceae) (Impson et al. 2009). Both groups have species which are concurrently invasive problem plants in some areas and valuable economic assets in others. This has polarized the way that they are perceived and has caused complications in their management, with a need to control them where they are problematic, while conserving them where they can be exploited. The invasiveness of both acacias and pines is attributable to their prolific production of seeds which germinate en masse after disturbance, especially fires, and enable the plants to resurge and proliferate in ever-increasing densities (Pieterse \& Cairns 1986, 1988; Richardson \& Higgins 1998). A key element in their control is therefore to suppress seeding. Thus, for over 30 years in South Africa, biological control agents have been specifically selected to reduce the seeding capacity of their hosts, and have been released and established on three commercially-exploited Australian Acacia species (Acacia melanoxylon R.Br., Acacia cyclops A.Cunn. ex G.Don and Acacia mearnsii De Wild.) (Dennill \& Donnelly 1991; Dennill et al. 1999; Impson et al. 2009, 2011). In all these cases, conflicts of interest have been avoided because the biological control agents are only associated with the reproductive components of their hosts and do not damage the valued timber, in the case of A. melanoxylon and A. cyclops, or in the case of black wattle, A. mearnsii, the wood (mostly used for wood pulp) or the bark, from which tannin is extracted.

The acceptance of biological control by producers of wattle-derived products provided a precedent which could be extrapolated to the pine industry. There was every possibility that cone-feeding insects, and possibly pathogens, could be used to reduce the seed production of pines without affecting the growth and productivity of plants in plantations, providing a sound basis and rationale for initiating a biological control programme against pines in South Africa.

\section{CONCERNS OF THE FORESTRY INDUSTRY}

From the time that the decision was made to proceed with a biological control programme against pines, a steering committee was formed on which forestry, biological control researchers, conservationists and the funding agency, the Department of Water Affairs and Forestry, were represented. This committee met annually and provided a forum where interested parties could exchange ideas on how specific issues should be dealt with during the risk assessment of potential agents. No restrictions were placed on attendance at these meetings, allowing anyone with an interest to participate. Several concerns were raised by the commercial forestry sector (Hoffmann et al. 2004), including:

(i) New species of pathogens that might infect pines could be introduced inadvertently with founder colonies of biological control agents.

(ii) The relatively recent escalation of pine pitch canker, Fusarium circinatum Nirenberg and O'Donnell (Hypocreales: Nectriaceae), in South Africa (Viljoen et al. 1997; Coutinho et al. 2007) heightened concerns that insect herbivores might enhance infection rates, and that the addition of cone insects to the system could aggravate the situation.

(iii) Commercial forests rely on seedlings to establish new plantations and to replenish forests that have been clear-felled. The supply of seeds could be rendered insufficient by introduced cone-feeding insects.

(iv) A proposal that seed orchards might be protected using routine pest control methods was countered by concerns that the use of these practices would not be received favourably by the Forestry Stewardship Council whose certification conditions include a requirement that pesticides should not be used in forests where timber is being harvested.

(v) Ongoing research is being undertaken to produce better trees for commercial pine plantations. The introduction of cone insects might affect each of the new cultivars differ- 
ently and unpredictably and cause problems for the development of these pine taxa for commercial purposes.

(vi) The use of biological control against insect pests that already cause problems in commercial pine forests could be affected by the allegedly-beneficial cone-destroying insects, in that the introduction of natural enemies intended for biological control of insect pest species might be prohibited in future if these parasitoids or predators were also able to exploit and limit the pine-cone-destroying agents.

(vii) Although only cone-feeding insects were to be considered for introduction into South Africa, assurances were needed that the insects would not damage the vegetative parts of the plants and thereby stunt growth of the pine trees or induce die back.

(viii) South African timber products are favoured by some importer countries because there are relatively few insect herbivores associated with pines in South Africa, a situation which minimizes the risk of inadvertent intercontinental movement of potential pests on timber products. The deliberate introduction of additional insect species, as biological control agents, might change this perception and negate these preferential trading opportunities.

(ix) Though not an acceptable or reasonable concern, forestry representatives were reluctant to condone a process that would pose any perceived threat at all to their industry.

Each of these concerns was considered as the programme commenced, thereby dictating much of the nature of the research that was done and ultimately determining its fate.

\section{THE TARGET PINE SPECIES}

The most problematic Pinaceae in South Africa include four North American species, Pinus radiata D.Don., Pinus patula Schltdl. \& Cham., Pinus taeda L. and Pinus elliottii Engelm., and three species from Europe, Pinus pinaster Aiton (Fig. 2), Pinus halepensis Mill. and Pinus pinea L. (Richardson \& Higgins 1998; Henderson 2001). Initially the intention was to tackle all these species with biological control. However, following discussions with forestry industry representatives, a decision was made to restrict the project to only two species,
$P$. pinaster and $P$. halepensis. Both $P$. pinaster and $P$. halepensis have minimal economic value and both are of European origin and not closely related to any of the North American species which make up all of the commercially exploited species in South Africa (Poynton 1979).

Pinus pinaster is native to western regions of the Iberian Peninsula, predominantly Portugal, while P. halepensis occurs throughout the coastal regions of the Mediterranean Sea. There are extensive forests of $P$. pinaster in the Bordeaux region of France but these are probably anthropogenic and relatively recent. All indications are that $P$. pinaster in South Africa originated from Portugal (Poynton 1979) so this became the focal point for selection and collection of potential biological control agents.

\section{POTENTIAL BIOLOGICAL CONTROL AGENTS}

The herbivorous insects and mites associated with Pinus species had been extensively studied before the initiation of the biological control programme (Turgeon et al. 1994), greatly facilitating the initial process of identifying candidates with potential for introduction into South Africa. Four species were short-listed. Two of these are moths, Dioryctria mendacella Staudinger and Dioryctria pineae Staudinger (Lepidoptera: Pyralidae), whose larvae feed endophagously within the cones of Pinus species, causing them to disintegrate before reaching maturity and thereby preventing any seed production. No progress was made with screening either Dioryctria species because neither could be reared successfully under cage conditions, and they were not considered further.

The third species was an eriophyid mite, reported to be Trisetacus nr ehmanii (Acari: Eriophyidae), which develops on the newly formed cones of $P$. pinaster, the only host on which it has been recorded (Roques \& El Alaoui El Fels 2005). Besides being highly sporadic and irregular in occurrence (causing localized damage in limited regions in some years, but generally not being noticeable on the trees), observations revealed that the damaged parts of the plants harboured not only T. nr ehmanii but a complex of eriophyid species whose individual roles in the system were not apparent (S. Neser, pers. comm.). The taxonomy and biology of each of these mite species needs to be elucidated before a proper risk assessment can be performed, 


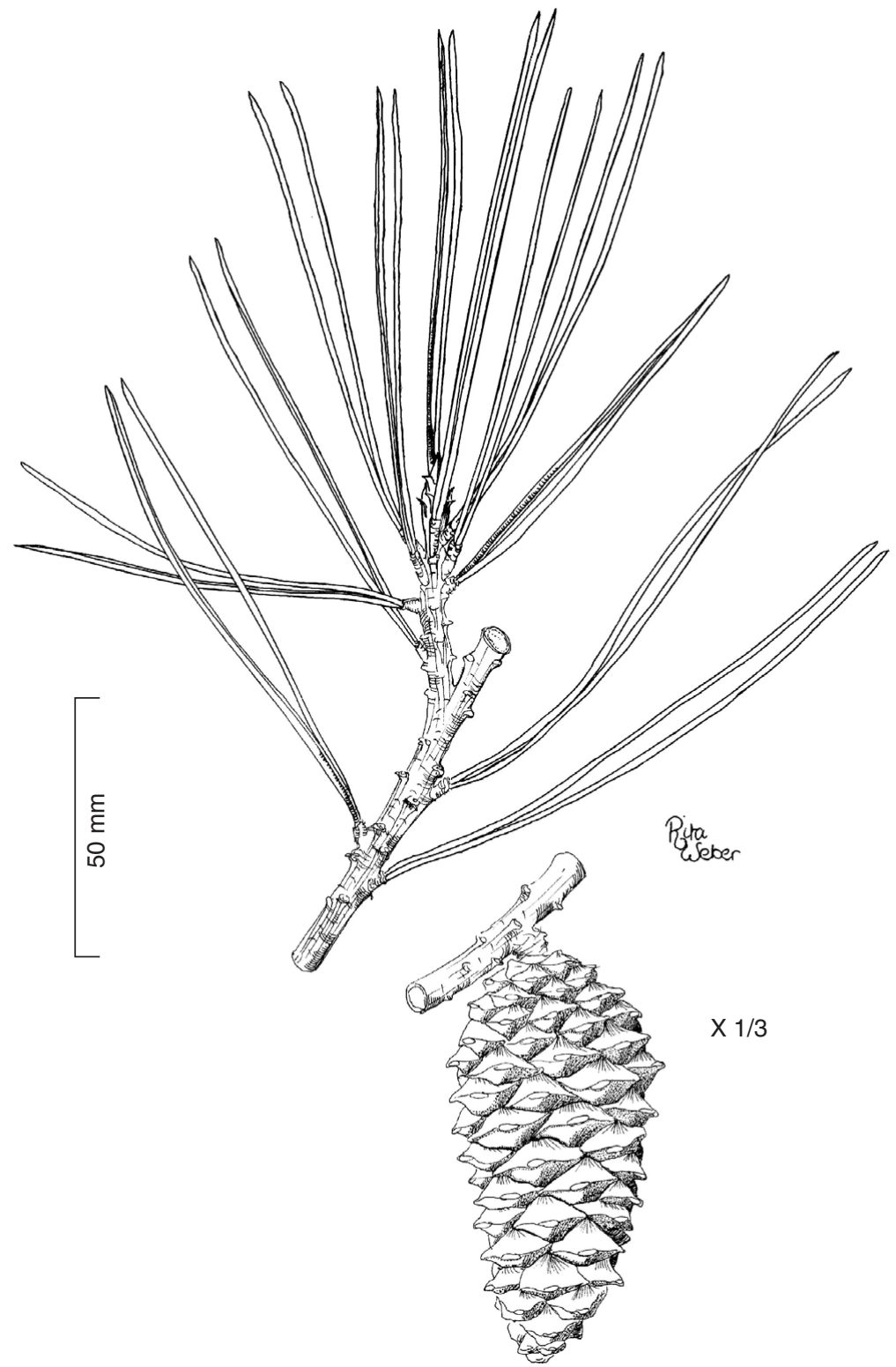

Fig. 2. Pinus pinaster. (Drawn by R. Weber, first published in Stirton (1978), South African National Biodiversity Institute, Pretoria.)

including whether the species causing the primary damage can persist on its own and whether it is suitably host-specific. Besides, the occurrence of infrequent and localized population outbreaks indicated that the eriophyid would not be likely to inflict sustained high levels of damage, a requirement for biological control to have any chance of success.
The remaining agent under consideration was a cone weevil, Pissodes validirostris Gyllenhal (Coleoptera: Curculionidae) whose larvae develop in immature cones, destroying the developing seeds and associated tissues (Roques 1976). The adults also feed superficially on actively growing terminal portions of shoots ('leaders') of their Pinus-hosts, particularly in spring. After the weevils 
withdraw from a feeding site, the perforations on the plant seep for an undetermined period as the exudates dry out and form a plug in the wound. The damage does not reduce growth of the plants or have any other measureable detrimental effect, even when artificially large populations of adults are confined on plants (A. Roques, unpubl.). This type of feeding activity was not expected to play any role in the dynamics of the biological control programme other than ensuring that the adult weevils could survive and then lay their eggs in the young pine cones.

At the start of the project, $P$. validirostris was known as a single, widespread, generalist species associated with almost all the pine species in Europe (Dormont \& Roques 2001). Field surveys early in the biological control programme indicated that there are several different forms of $P$. validirostris associated with different pine species in different regions of Europe, a discovery which considerably enhanced the prospects of finding a suitable taxon for use against pines in South Africa and leading to the prioritization of P. validirostris as the candidate of choice. Results of host-specificity studies in France supported the taxonomic divergence of $P$. validirostris and led Roques et al. (2004) to conclude that ' $P$. validirostris probably consists of a complex of sibling species specialized on different host pines' and that, in terms of its host specificity, the Portugueseprovenance of $P$. validirostris 'originating from $P$. pinaster appear(s) to be suitable for release in South Africa.'. Molecular studies confirmed that $P$. validirostris from across Europe comprises more than one haplotype (G. Roux-Morabito, unpubl.).

\section{PINE PITCH CANKER, FUSARIUM CIRCINATUM}

While the host specificity of the provenance of P. validirostris from P. pinaster in Portugal was being investigated in arboreta and insectaria in France, the incidence of pine pitch canker was escalating in South Africa. In 1999 the pathogen was associated only with plants being cultivated in nurseries and was not manifest in plantations. In the ensuing period circumstances changed and the fungus appeared in some areas in plantations with young trees (Coutinho et al. 2007).

With the escalation in pine pitch canker, the many species of insect herbivores already associated with pines in South Africa (Tribe 1992, 1995) were implicated as possible carriers of pitch canker spores between plants (Hurley \& Govender 2007) or, through their feeding damage on the plants, of creating avenues for ingress of the pathogen. Proposals that another herbivorous species might be deliberately introduced into the country were met with demands from forestry representatives for an absolute guarantee that only commercially unimportant species would be utilized as hosts by the weevils and that, if there was any likelihood of incidental feeding damage on commercial pine species, this would not enhance infection rates by pine pitch canker. To satisfy these demands, it became paramount to show that there would be no association between the pathogen and P. validirostris before embarking on the process of seeking official approval for the weevil to be cleared for introduction and release in South Africa.

A series of feeding trials on leader shoots of different commercial pine species were conducted as choice tests in cages under quarantine in South Africa (J.H. Hoffmann, unpubl.). The results showed that the adults fed as readily on $P$. pinea, P. taeda, $P$. radiata and the hybrid, P. elliotii $\times$ chiapensis, as they did on P. pinaster, while feeding occurred at lower levels on all of the other species of Pinaceae that were tested, Pinus tecunumanii (Eguiluz \& Perry) Styles, P. patula, Pinus greggii Engelm. ex Parl., Pinus chiapensis (Martínez) Andresen and P. elliotii. The conclusion that was drawn was that, even though $P$. validirostris is host specific in its immature stages in cones, the adults can feed on the leaders of any pine species they encounter, with implications for transmission of pitch canker which needed to be resolved.

A set of experiments followed which showed that the adult beetles do not transmit spores as they move from infected trees, but that adult feeding sites on leader shoots can serve as points of ingress for the pathogen, thereby enhancing the incidence of infection on damaged plants (Lennox et al. 2009). The implications of this finding prompted much deliberation. The results clearly showed that there is potential for P. validirostris to enhance the progression of pitch canker on any pine species that is damaged.

This realization needed to be balanced against the probability that $P$. validirostris adults will encounter and feed on cultivated pine trees. The adult beetles are reputed to be slow dispersers, generally remaining in close proximity to the trees on which they developed as larvae. There is there- 
fore a very slight probability that adults would ever occur on cultivated pines, since none of these are suitable larval hosts for the weevil. Nevertheless, anticipating how an insect will respond to the novel conditions it encounters when moved to a new area for biological control is highly problematic. No guarantee can be given that hosts other than P. pinaster will not be used for leader-feeding by $P$. validirostris were it to be released in South Africa. On balance, and given the potential magnitude of the problem were leader-feeding to eventuate, a decision was made to discontinue the project, at least until the circumstances around pitch canker in South Africa are better understood.

\section{DISCUSSION}

The decision not to introduce the cone-weevil, P. validirostris, as a biological control agent against P. pinaster and P. halepensis in South Africa, was not taken lightly. A group of experts concerned about pines as invasive species in South Africa remains firmly of the opinion that the decision was premature and not fully justified. They particularly emphasize that it is misleading to base the decision on the fact that $P$. validirostris feeds on the shoots of non-target pine species under cage conditions, contending that it is highly unlikely that pine species other than the natural hosts (P. pinaster, $P$. pinea and $P$. halepensis) will be used by P. validirostris for leader-feeding under field conditions. The problem is that there is doubt about this assumption.

Besides the costs that could accrue if the coneweevils damaged commercial pines and were vectors of pitch canker, the apportionment of blame could have far-reaching consequences for biological control in general and place it in a negative light both nationally and internationally. The situation may change because pine trees in South Africa already host several herbivorous insect species which have the potential to transmit pitch canker between trees. If they do, pitch canker will become widespread anyway and the addition of one more herbivore species, in the form of a biological control agent, may not contribute significantly to the pitch canker problem. Furthermore, concerns about $P$. validirostris being associated with pitch canker could be reconsidered if resistant genotypes of pines are used to replenish plantations in the future and pitch canker diminishes as a threat to the forestry industry.

There is another consideration concerning the proposed introduction of $P$. validirostris into South Africa for the biological control of pines. Plans are afoot to use $P$. validirostris as a source of parasitoids for the biological control of a congeneric species, Pissodes nemorensis Germar. (Coleoptera: Curculionidae), a stem borer which is already a widespread pest of pines in South Africa. Were any of these parasitoids to be introduced before or after $P$. validirostris, the chances of $P$. validirostris succeeding as a biological control agent against pines would become increasingly less likely.

Pines do not sprout when felled, but they are difficult to control because post-fire dispersal of the winged seeds allows them to spread over considerable distances in high numbers. Invasive stands of pines have now established, and are becoming denser, across large, rugged and essentially inaccessible areas of the fynbos mountain areas where, for all practical purposes, it is impossible for mechanical clearing teams to be effective. Le Maitre et al. (2000) estimated that in 1996 there were 65000 'condensed' hectares of pines in the fynbos biome. Data from the WfW programme show that, between 1999 and 2009, 74519 'condensed' hectares of pines was cleared at a cost of R86 million (i.e. more than was estimated to be there in the first place), yet pines still dominate the landscape, and the situation is even worse than it was previously assumed to be (Cowling et al. 2009). Under these circumstances, mechanical control cannot succeed and the only hope of reversing these trends is to find some form of biological control solution.

Although a decision was taken to suspend work on biological control of pines, the question of whether or not it should continue remains open. There are convincing arguments which suggest that, rather than unduly emphasize the legitimate concerns of foresters, biological control researchers have an obligation to consider equally seriously the concerns of conservationists and the consequences of not continuing with this work. Using taxpayers' money to subsidize a non-viable enterprise, while at the same time ignoring the immense environmental and economic costs associated with such an enterprise, is not defendable. In comparison with the significant challenges facing the pine-based forestry industry in the fynbos biome particularly, the risks associated with the introduction of a carefully-tested, cone-feeding weevil (which is unlikely to associate with the commercial pine species anyway), are insignifi- 
cant. Resolving this divergence of opinion is the challenge going forward.

\section{ACKNOWLEDGEMENTS}

Sincere thanks to the Working for Water Programme of the South African Department of Water Affairs, the University of Cape Town and the National Research Foundation for providing the funding which enabled this intriguing research programme to be pursued. The untiring involvement of A. Roques, INRA, France, in the project

\section{REFERENCES}

BROCKERHOFF, E.G. \& KAY, M. 1998. Prospects and risks of biological control of wilding Pinus contorta in New Zealand. Proceedings of the New Zealand Plant Protection Conference 51: 216-223.

BROCKERHOFF, E.G., HOFFMANN, J.H. \& ROQUES, A. 2004. Is biological control an option for the management of wilding pines (Pinus spp.) in New Zealand? In: Hill, R.L., Zydenbos, S.M.\& Bezar, C.M. (Eds) Managing Wilding Conifers in New Zealand: Present and Future. 65-78. New Zealand Plant Protection Society, Christchurch.

COUTINHO, T.A., STEENKAMP, E.T., MONGWAKETSI, K., WILMOT, M. \& WINGFIELD, M.J. 2007. First outbreak of pitch canker in a South African pine plantation. Australasian Plant Pathology 36: 256-261.

COWLING, R.M., RICHARDSON, D.M. \& PIERCE, S.M. (Eds) 1997 Vegetation in Southern Africa. Cambridge University Press, Cambridge, U.K.

COWLING, R., VAN WILGEN, B. \& KRAAIJ, T. 2009. How no-man's land is becoming everyone's problem: Runaway pine invasions in the Outeniqua and Tsitsikamma mountains. Veld E Flora Sep., 147-149.

DE LANGE, W.J. \& VAN WILGEN, B.W. 2010. An economic assessment of the contribution of biological control to the management of invasive alien plants and to the protection of ecosystem services in South Africa. Biological Invasions 12: 4113-4124

DENNILL, G.B. \& DONNELLY, D. 1991. Biological control of Acacia longifolia and related weed species (Fabaceae) in South Africa. Agriculture, Ecosystems and Environment 37: 115-135.

DENNILL, G.B., DONNELLY, D., STEWART, K. \& IMPSON, F.A.C. 1999. Insects agents used for the biological control of Australian Acacia species and Paraserianthes lophantha (Willd.) Nielsen (Fabaceae) in South Africa. In: Olckers, T. \& Hill, M.P. (Eds) Biological Control of Weeds in South Africa (1990-1998). African Entomology Memoir 1: 45-54.

DORMONT, L. \& ROQUES, A. 2001. Why are seed cones of Swiss stone pine (Pinus cembra) not attacked by the specialized pine cone weevil, Pissodes validirostris? A case of host selection vs. host suitability. Entomologia Experimentalis et Applicata 99: 157-163.

DWAF. 2004. Key issue paper for a policy on transfers of state owned industrial plantations. Department of Water Af- has been invaluable. G. Roux-Morabito, University of Orleon, France, conducted the molecular studies which confirmed that $P$. validirostris comprises different haplotypes in Europe. S. Neser and C. Craemer, ARC-PPRI, South Africa, investigated and provided clarity on the status of the mites associated with conelets on $P$. pinaster in France. M. Keinhaus (INRA) provided technical support in France while C. Kleinjan (UCT), J. Post, K. Appollis and A. Adonis (all ARC-PPRI) assisted while $P$. validirostris was being reared and investigated in quarantine in South Africa.

fairs and Forestry, Pretoria, South Africa. Online at: http://www2.dwaf.gov.za/dwaf/cmsdocs/Elsa/Docs/ Transfers/KIP\% 20Policy\% 20on \% 20Transfers\% 202004.pdf (accessed March 2011).

DWAF. 2005. Forestry change programme: business process analysis report. Forestry transfers process, Version 5.0. Department of Water Affairs and Forestry, Pretoria, South Africa. Online at: http://www2.dwaf.gov.za/ dwaf/cmsdocs/Elsa/Docs/Transfers/Business $\%$ 20Process $\%$ 20Analysis $\% 20$ Report $\% 20$ Transfers $\% 2$ 02005.pdf (accessed March 2011).

GODSMARK, R. 2010. South African Forestry: Forestry facts and figures. Online at: http://www.forestry. co.za/uploads/file/... /sa_forestry_industry_2010_ colour.ppt (accessed March 2011).

HENDERSON, L. 2001. Alien Weeds and Invasive Plants: A Complete Guide to Declared Weeds and Invaders in South Africa. Plant Protection Research Institute Handbook No. 12. Agricultural Research Council, Pretoria, South Africa.

HOFFMANN, J.H., ROQUES, A., ROUX-MORABITO, G. \& LENNOX, C. 2004. Prospects for biological control of wilding pines in South Africa: are we barking up the wrong tree? In: Hill, R.L., Zydenbos, S.M. \& Bezar, C.M. (Eds) Managing Wilding Conifers in New Zealand: Present and Future.113-122. New Zealand Plant Protection Society, Christchurch.

HURLEY, B.P. \& GOVENDER, P. 2007. Fungus gnats and other Diptera in South African forestry nurseries and their possible association with the pitch canker fungus. South African Journal of Science 103: 42-46.

IMPSON, F.A.C., HOFFMANN, J.H. \& KLEINJAN, C.A. 2009. Biological control of Australian Acacia species. In: Muniappan, R., Reddy, G.V.P. \& Raman, A. (Eds) Biological Control of Tropical Weeds using Arthropods. 38-62. Cambridge University Press, Cambridge, U.K.

IMPSON, F.A.C., KLEINJAN, C.A., HOFFMANN, J.H., POST, J.A. \& WOOD, A.R. 2011. Biological control of Australian Acacia species and Paraserianthes lophantha (Willd.) Nielsen (Mimosaceae), in South Africa. African Entomology 19(2): 186-207.

KAY, M. 1994. Biological control for invasive species. New Zealand Forestry 39: 35-37.

LE MAITRE, D.C. 1998. Pines in cultivation: a global view. In: Richardson, D.M. (Ed.) Ecology and Bio- 
geography of Pinus. 407-449. Cambridge University Press, Cambridge, U.K.

LE MAITRE, D.C., VERSFELD, D.B. \& CHAPMAN, R.A. 2000. The impact of invading alien plants on surface water resources in South Africa: a preliminary assessment. Water SA 26: 397-408.

LENNOX, C.L., HOFFMANN, J.H., COUTINHO, T.A. \& ROQUES, A. 2009. A threat of exacerbating the spread of pitch canker precludes further consideration of a cone weevil, Pissodes validirostris, for biological control of invasive pines in South Africa. Biological Control 50: 179-184.

LOUW, W.J.A. 2004a. General history of the South African forest industry: 1975 to 1990 . South African Forestry Journal 200: 77-86.

LOUW, W.J.A. 2004b. General history of the South African forest industry: 1991 to 2002. South African Forestry Journal 201: 65-76.

LOUW, W.J.A. 2006. General history of the South African forest industry: 2003 to 2006. South African Forestry Journal 208: 79-88.

MORAN, V.C., HOFFMANN, J.H., DONNELLY, D., ZIMMERMANN, H.G. \& VAN WILGEN, B. 2000. Biological control of alien, invasive pine trees (Pinus species) in South Africa. In: Spencer, N.R. (Ed.) Proceedings of the X International Symposium on Biological Control of Weeds. 941-953. Bozeman, Montana, U.S.A.

PIETERSE, P.J. \& CAIRNS, A.L. 1986. The effect of fire on an Acacia longifolia seed bank in the south western Cape. South African Journal of Botany 52: 233-236.

PIETERSE, P.J. \& CAIRNS, A.L. 1988. The population dynamics of the weed Acacia longifolia (Fabaceae) in the absence and presence of fire. South African Forestry Journal 145: 25-27.

POYNTON, R.J. 1979. Tree Planting in Southern Africa. Volume 1. The Pines. Department of Forestry, Pretoria, South Africa.

RICHARDSON, D.M. \& HIGGINS, S.I. 1998. Pines as invaders in southern hemisphere. In: Richardson, D.M. (Ed.) Ecology and Biogeography of Pinus. 450-473. Cambridge University Press, Cambridge, U.K.

RICHARDSON, D.M., VAN WILGEN, B.W., HIGGINS, S.I., TRINDER-SMITH, T.H., COWLING, R.M. \& McKELLY, D.H. 1996. Current and future threats to plant biodiversity on the Cape Peninsula, South Africa. Biodiversity and Conservation 5: 607-647.

ROQUES, A. 1976. Observations sur la biologie et l'écologie de Pissodes validirostris Gyll. (Coléoptère Curculionidae) en forêt de Fontainebleau. Annales de Zoologie, Ecologie Animale 8: 533-542.

ROQUES, A. 1983. Les Insectes Ravageurs des Cônes et Graines de Conifères en France. INRA, Service des Publications, Versailles, France.
ROQUES, A. \& EL ALAOUI EL FELS, M.A. 2005. Overview of the arthropod fauna that colonises seed cones in the Mediterranean region. In: Lieutier, F. \& Ghaioule, D. (Eds) Entomological Research in Mediterranean Forest Ecosystems. 59-78. Institut National de la Recherche Agronomique, Paris, France.

ROQUES, A., ROUX-MORABITO, G., HOFFMANN, J.H., KLEINHENTZ, M. \& GOUROV, A. 2004. Determining the suitability of a European cone weevil, Pissodes validirostris, for biological control of invasive pines in South Africa. In: Cullen, J.M., Briese, D.T., Kritikos, D.J., Lonsdale, W.M., Morin, L. \& Scott, J.K. (Eds) Proceedings of the XI International Symposium on Biological Control of Weeds. 315-321. CSIRO Entomology, Canberra, Australia.

SCOTT, D.F. \& LESCH, W. 1996. The effects of clearing and clearfelling of an indigenous forest on streamflow, stormflow and water quality. South African Forestry Journal 175: 1-14.

STIRTON, C.H. (Ed.) 1978. Plant Invaders Beautiful but Dangerous. Department of Nature and Environmental Conservation of the Cape Provincial Administration, Cape Town, South Africa.

TRIBE, G.D. 1992. Colonisation sites on Pinus radiata logs of the bark beetles, Orthotomicus erosus, Hylastes angustatus and Hylurgus ligniperda (Coleoptera: Scolytidae). Journal of the Entomological Society of Southern Africa 55: 77-84.

TRIBE, G.D. 1995. The woodwasp Sirex noctilio Fabricius (Hymenoptera: Siricidae), a pest of Pinus species, now established in South Africa. African Entomology 3: 215-217.

TURGEON, J.J., ROQUES, A. \& DE GROOT, P. 1994. Insect fauna of coniferous seed cones: diversity, host plant interactions and management. Annual Review of Entomology 39: 179-212.

VAN LILL, W.S., KRUGER, FJ. \& VAN DYK, D.B. 1980. The effect of afforestation with Eucaluptus grandis Hill ex Maiden and Pinus patula Schlecht. \& Cham. on streamflow from experimental catchments at Mokubalaan, Transvaal. Journal of Hydrology 48: 107-118.

VAN WYK, D.B. 1987. Some effects of afforestation on streamflow in the Western Cape Province, South Africa. Water South Africa 14: 31-36.

VENTER, J.H. 2001. Forest restructuring: seeing the wood for the trees. Engineering News, 23 November 2001. Online at: http://www.engineeringnews.co. $\mathrm{za} /$ article/forest-restructuring-seeing-the-wood-forthe-trees-2001-11-23.

VILJOEN, A., WINGFIELD, M.J., MARASAS, W.F.O. \& COUTINHO, T.A. 1997. Pitch canker of pines - a contemporary review. South African Journal of Science 93: 411-413. 